\title{
Moral Duties and Juridical Duties: The Ambiguity of Legal Ethics Considered Through the Prism of Kant's Metaphysics of Morals
}

\author{
Alessandro Ferrara ${ }^{1}$ (i) \\ ${ }^{1}$ Magna Graecia University of Catanzaro, Catanzaro, Italy \\ Corresponding author: a.ferrara@unicz.it
}

(Received 26 January 2021; accepted 11 May 2021)

\begin{abstract}
My article aims to analyze the conflict between the duties deriving from the supranational deontological codification under a philosophical point of view. Specifically, I will discuss both rules implying the independence of a lawyer and the obligation to ensure that the legitimate interests of the client and the proper administration of justice are protected. I will conduct an analysis about the relationship between moral and juridical duties through a few parts from The Metaphysics of Morals, published by Immanuel Kant in 1797. Afterwards, I will try to verify if Kant's conception of moral and juridical duties can provide a lawyer with the guidelines for the conflict resolution. I will suggest a meeting point capable of satisfying at the same time those interests whose protection is conflictingly established by the ethical code, and which is represented by the Alternative Dispute Resolution, precisely by the Assisted Negotiation procedure. Ultimately, I will propose an approach based on the identification of an agreement as a way to solve the conflict between the lawyer's duties.
\end{abstract}

Keywords: Kant; metaphysics of morals; moral and juridical duties; legal ethics; alternative dispute resolutions

\section{A. Introduction}

The musings over the influence of the legal ethics upon the role of a lawyer in the societyexploded within Anglo-American countries in the $1970 s^{1}$ - have recently developed even in Europe, where the civil law system was born and the role of the judge is seen as the one and only application of legal doctrine. Similarly, the supranational codification of the fundamental principles of legal ethics has developed lately. In the modern conception of their function, these principles are designed to guide the lawyer's behavior both inside and outside the legal professional practice. Some contradictions between the founding deontological principles seem to persist in all

\footnotetext{
Alessandro Ferrara PhD candidate in Theory of Law and European Economic Legal Order at Magna Graecia University of Catanzaro (Italy) and plus visiting PhD at the Vrije University of Amsterdam (Netherlands). This publication is co-financed with the support of the European Commission, the European Social Fund and the Calabria Region. The author is solely responsible for this publication and the European Commission and the Calabria Region decline any responsibility for the use that may be made of the information contained therein.

${ }^{1}$ For a reconstruction of the Anglo-American deontological debate, see, e.g., Katherine R. Kruse, The Jurisprudential Turn in Legal Ethics, 53 ArIz. L. Rev. 493 (2011); Russ G. Pearce, The Legal Profession as a Blue State: Reflections on Public Philosophy, Jurisprudence and Legal Ethics, 75 Fordham L. REV. 1339, 1339-65 (2006).
} 
their pervasiveness, even in the aforementioned new codifications. The analysis of these principles will be the starting point of my considerations. The essential crux of legal ethics is mainly focused on the analysis of the lawyers social function in relation to her obligation to act in the client's best interests. As for this specific point, and in order to frame the issue emerging from the regulatory conflict, Andrea Romeo wondered:

[W] hether the lawyer is required to carry out her obligations acting as an indifferent "hiredgun" who appears to be impartial about the moral status of her client's objectives and ethically loyal to these interests; or the lawyer should conflict with the client's greed underlining the substantial injustice of these actions, in the name of a substantial concept of justice and a more liberal vision of her legal profession. ${ }^{2}$

Conflict implications therefore emerge when the lawyer acts within legitimate legislative parameters, allowing her client to satisfy his or her own interests and at the same time creating damage to third parties. ${ }^{3}$ From a moral point of view, causing this damage could be considered as unjust, ${ }^{4}$ and in some cases contrary to a specific interpretation of the notion related to the correct administration of justice. ${ }^{5}$

Even so, I will focus on this problem taking into consideration Kant's theories based on the distinction between ethics and law, specifically between moral and juridical duties, acknowledged in The Metaphysics of Morals. ${ }^{6}$ I will try then to verify if some parameters could be set up for the resolution of the aforementioned antinomies, encouraging the lawyer to abandon an amphibious ${ }^{7}$ profile, and to benefit from the adoption of standards that lead to a righteous behavior.

Subsequently, I will try to propose an effective solution that could represent a meeting point between the different perspectives of the lawyer's social function.

Before starting the analysis, however, it is useful to briefly clarify the meaning of 'deontology,' a concept that appears several times in my article.

Although it is possible to find direct and indirect references already in Plato and Aristotle, the genesis of the term is to be attributed to Jeremy Bentham, who coined and used it around 1813 as a philosophical neologism in his work Deontology. ${ }^{8}$ As Simone Cremaschi pointed out in his Italian edition of Jeremy Bentham's Deontology, this term-made up by the union of the Greek words deon (duty) and logos (speech)_-was initially chosen by Bentham to designate private ethics as opposite of political ethics. ${ }^{9}$

Therefore, deontology could be considered as a descendant of the ethical (from the Greek word ethos, 'custom, habit') and moral principles (from the Latin word mores, 'manner, usage, or habit')

\footnotetext{
${ }^{2}$ Andrea Romeo, Legalità, Giustizia e Deontologia. La Funzione degli Avvocati tra Giustizia Sostanziale ed Etica Professionale, 2 ORDINES 236, (Alessandro Ferrara trans., 2015).

${ }^{3} I d$.

${ }^{4} \mathrm{Within}$ this work the concept of justice will have to be interpreted in the light of the context of application, sometimes in the sense of compliance with the normative dictation and sometimes in the sense of correspondence to moral values.

${ }^{5}$ Cf. Aristotle, Nicomaechean Ethics (Roger Crisp ed., Cambridge Texts in The History of Philosophy 2014); ARIstotle, Politics, (Thornton Lockwood \& Thanassis Samaras eds., Cambridge University Press 2015); Plato, The Republic (G.R.F. Ferrari ed., Tom Griffith trans., Cambridge Texts in the History of Political Thought 2000); JoHN Rawls, A Theory of Justice (Harvard University Press 1971); Michael Sander, Liberalism and The Limits of Justice (Cambridge University Text 2012); Giovanni ZanetTi, La Nozione di Giustizia in ARistotle (Il Mulino ed., 1993).

${ }^{6}$ See Immanuel Kant, The Metaphysics of Morals 9-22 (Mary Gregor trans., Cambridge Texts in the History of Philosophy 1996) (1797); See also Roger J. Sullivan, Introduction, id. at vii-xxvi.

${ }^{7}$ See Massimo la Torre, Deontologia, Altri Seminari di filosofia del diritTo, 102 (Massimo La Torre \& Giovanni Zanetti eds., Rubettino, 2010).

${ }^{8}$ See Jeremy Bentham, Deontology, together with a table of the Spring of Action and Article on Utilitarianism (Amnon Goldworth ed., Clarendon Press, 1983).

${ }^{9}$ See Jeremy Bentham, Deontology 9 (Simone Cremaschi ed., La Nuova Italia, 2000).
} 
applied in a professional field and developed simultaneously with the professions themselves. ${ }^{10} \mathrm{I}$ refer specifically to those intellectual activities at high-moral risk ${ }^{11}$ that subsequently positivized the relative systematic corpus and the subsequent provision of sanctions in case of non-compliance with the rules specified therein. ${ }^{12}$

Based on the above, the term deontology will refer to a set of rules of conduct deriving from ethical and moral principles and related to an intellectual profession; those principles that are commonly and customarily applied by the professionals over a relevant period of time so as to become positive within a code or a regulatory act. ${ }^{13}$

Therefore, the first part of my article will identify the conflicting regulatory elements through the analysis of the principles stated in the Charter of Core Principles of the European Legal Profession, and the Code of Conduct for European Lawyers, respectively adopted by the CCBE (Conseil des Barreaux Européens) in November 2006 and 2007.

I will also take into consideration what is expressed in the General Principles for the Legal Profession, adopted by the International Bar Association-the foremost organization for international legal practitioners, bar associations and law societies-on September 20, 2006, with the aim of directly addressing the behavior of lawyers all over the world regardless of the respective national borders of reference, and above all to standardize the national professional associations in the codification of ethical rules.

Subsequently, I will try to verify if the suggestion about a lawyer trying to adopt the Alternative Dispute Resolution-avoiding the judicial protection of her client's rights and excluding the contribution of third parties from the resolution of the conflict-acts according to higher ethical procedures-resorting to the assisted negotiation procedure-placing herself in a median point between the various interests at stake.

Having said that, I am aware that my proposal may have some weaknesses-such as the imbalance of power between the parties and the presence of some controversial cases-which could limit its practical application, but it might be a starting point for further reflection.

\section{B. The Contradiction Within the Supranational Deontological Codes}

In order to be able to frame the reference sources of the subsequent philosophical analysis, I will try to identify the fundamental ethical principles whose codification probably generated the most debated contradictions within the legal ethics theories referred to the legal profession. These may

\footnotetext{
${ }^{10}$ The idea of the existence of general duties, common to all human beings, and of special duties, linked to a specific profession and social position, is present in the thought of Francis Bacon. In Bacon's work, The Advancement of Learning (1605) and in his essay Of Judicature (1612) he affirms and supports the necessary link between ethics and profession on the basis of a theory of the division of labor. $C f$. Friedrich Pollock, A First BooK of Jurisprudence for Students of THE COMmON LAW (Macmillan, 1911).

${ }^{11}$ See Claudio Sartea, Deontologia. Filosofia del Lavoro Professionale 24 (Alessandro Ferrara trans., Giappichelli, 2010).

${ }^{12}$ The reflection on the effect of morality within the legal professions was the subject of a stir philosophical debate. Oliver Wendell Holmes and J.L. Hill, as supporters of legal realism, argue an excessive interference of philosophy within the law, stating that this is "the prophecy of what the courts will do...." Oliver Wendell Holmes, The Path of the Law, in PHILOSOPHY OF LAw of Legal Theory (Dennis Patterson ed., Blackwell, 2003). Or that "the law is what the judge ate for breakfast." J.L. Hill, The Political Centrist (Vanderbilt University Press 2009). This last sentence is attributed to Jerome Frank, federal judge of the U.S. Court of Appeals for the Second Circuit. Conversely, moral activists like William H. Simon deem it appropriate to include moral evaluations within the reflection related to the forensic activity. See William H. SimON, THE PRACTICE OF JUstice: A Theory of LAWYers' Ethics 138 (Harvard University Press 1998) ("Lawyers should take those actions that, considering the relevant circumstances of the particular case, seem likely to promote justice.").

${ }^{13}$ See generally Remo Danovi, Deontologia e GiUstizia (Giuffrè ed.., 2003); Claudio Sartea, L'Emergenza Deontologica. Contributo allo Studio dei Rapporti Tra Deontologia Professionale, Etica e Diritto (Aracne ed., 2007).
} 
include the principle of independence, the principle of protecting the client's interest and the principle of protecting the proper administration of justice. ${ }^{14}$

The principle of independence is certainly in a central position within the analyzed supranational ethical codes, and it is defined as an indissoluble principle of the legal profession:

The lawyer must be independent of the state and other powerful interests, and must not allow his or her independence to be compromised by improper pressure from business associates. $^{15}$

The many duties to which a lawyer is subject require the lawyer's absolute independence, free from all other influence, especially such as may arise from his or her personal interests or external pressure. Such independence is as necessary to trust in the process of justice as the impartiality of the judge. ${ }^{16}$

A lawyer shall maintain and be afforded protection of independence to allow him or her to give his or her clients unbiased advice or representation. ${ }^{17}$

The reading of the various systems, through which this principle has been codified, highlights the codifier's idea of a correct exercise of the legal profession-in relation to its social function-outside any external influence.

In this perspective, the only incentive to guide the lawyer's action seems to be the simple and consistent application of the law. In fact, precisely by virtue of independence from her client, the lawyer will be able to clearly identify the ways to ensure the best protection of his or her legal interest. $^{18}$

\footnotetext{
${ }^{14}$ The identification of the fundamental principles that I have outlined derives from a prior analysis of their consistency within the main European national codes of ethics, and from their subsequent comparison with the supranational codes of conduct. As an example, the principle of independence can be found in the Italian Codice Deontologico Forense, [Code of Conduct for Italian Lawyers], Art. 9: "A lawyer shall practice his professional activity with respect to the duties of independence.” https://www.ccbe.eu/fileadmin/speciality_distribution/public/documents/National_Regulations/DEON_ National_CoC/EN_Italy_Code_of_Conduct_for_Italian_Lawyers.pdf; in the Dutch Advocatenwet [Act on Advocates], Article 10 bis: "The lawyer in the exercise of his profession is independent of his client, third parties and other businesses [...]" (Alessandro Ferrara trans.) https://wetten.overheid.nl/BWBR0002093/2015-01-01\#Afdeling2; in the French Code de Deontologie [Code of Conduct], Article 1: "Les principes essentiels de la profession d'avocat", establishing that: "the legal profession is a liberal and independent profession regardless of its mode of practice”, (Alessandro Ferrara trans.), http://codedeonto.avocatparis.org/acces-par-articles?id=216; in the German Bundesrechtsanwaltsordnung [The Federal Lawyers' Act] and the Berufsordnung [Code of Conduct for Lawyer], which establish as a fundamental principle that the lawyer is an independent body in the administration of justice, https://www.gesetze-im-internet.de/brao/;. Finally, without claiming to be complete, but simply in order to make the reader understand the modus operandi of my investigation, I want to refer to the Handbooks of the Solicitor Regulation Authority (SRA) and the Bar Standards Board (BSB), which invite the lawyers to not allow their independence to be compromised, https://www.sra.org.uk/solicitors/handbook/ handbookprinciples (Part 1: SRA Principles; 23, 2019) and to maintain their Independence, https://www. barstandardsboard.org.uk/for-barristers/compliance-with-your-obligations/the-core-duties.html (Core Duty 4; Oct. 24, 2019).

${ }^{15}$ Charter of Core Principles of the Eur. Legal Prof. Principle (a) (Council of Bars and Law Soc'ys of Eur. 2008).

${ }^{16}$ Code of Conduct for Eur. Law., $\$ 2.1 .1,15$ (COUnCIL OF BARS AND L. Soc’ys of Eur. 2006).

${ }^{17}$ Gen. Principles for Legal Pro. Principle 1, 2 (Int'L Barrister Ass'N 2006).

${ }^{18}$ See Massimo La Torre, L’Avvocato E il Concetto Di DiritTo, (Rubbettino ed., 2013) (suggesting that the lawyer must be guided by the criterion of the effectiveness of the defense itself, without giving space to their opinions, ideas or beliefs regarding the defense case). See also GIOvanni Tarello, Due Interventi in Tema di Deontologia 207-218 (1 MATERIALI PER UNA STORIA DELla CUlTURA GIURIDICA, XII 2009) (arguing that the defender must feel and act exclusively as a defender, without ever acting as an auxiliary or collaborator of the judge. This would make the defense as effective as possible within the only limit of the mandatory provisions of the law.).
} 
At the same time, the legal assessments of the lawyer must not be influenced either by state bodies or by personal economic interests, ${ }^{19}$ so that her role-as cold and objective legal advisor on the client's case - can trace the one of the judge in advance. ${ }^{20}$

The next step taken by the supranational ethical codification is precisely aimed at the discipline of the client-lawyer relationship, a fundamental principle of the legal profession since the Roman law system, and according to which the lawyer must have as main objective, indeed unique for somebody, the protection of the client's interest.

The legal profession was born to be a free service to people (ad auxilium vocatus, ${ }^{21}$ "the one called to help"), with the sole purposes of benevolence, elevation and protection of the social and political status.

Even the term honorarium, currently used to indicate the fee for a professional activity, derives from a voluntary payment that was given to the advocatus only for honorary reward. In addition, the Lex Cincia (204 BC) forbade lawyers from being compensated after pleading a case, and as Tacito recorded: "Ne quis ob causam orandam pecuniam donumve accipiat"22 (no one should accept money or gifts for pleading a case).

Obviously, the development and evolution of the legal profession have led to significant changes over time, but despite this, the basic relationship and the function covered by this role have probably been the same for over 2,000 years. By virtue of this, the supranational codes of ethics govern this fundamental relationship through the following principle: "Loyalty to the client is of the essence of the lawyer's role"23; "Subject to due observance of all rules of law and professional conduct, a lawyer must always act in the best interests of the client and must put those interests before the lawyer's own interests or those of fellow members of the legal profession"24; "A lawyer shall treat the interests of his or her clients as paramount, subject always to his or her duties to the Court and the interests of justice, to observe the law and to maintain ethical standards." 25

Probably, it is precisely the indeterminacy of the relationships between these rules, or codes, that generates the conflict I will try to analyze in the following pages. As regards the aspect that I am interested in taking into consideration, it may be useful to quote the Charter of Core Principles of the European Legal Profession-that I have already mentioned previously-which provides some points for reflection on the social function of the lawyer, together with an overview on the issues regarding the deontological codification:

We have characterized part of the role of the lawyer as acting as a participant in the fair administration of justice. The same idea is sometimes expressed by describing the lawyer as an 'officer of the court' or as a 'minister of justice'. A lawyer must never knowingly give false or misleading information to the court, nor should a lawyer ever lie to third parties in the course of his or her professional activities. These prohibitions frequently run counter to the immediate interests of the lawyer's client, and the handling of this apparent conflict between the interests of the client and the interests of justice presents delicate problems that the lawyer is professionally trained to solve. The lawyer is entitled to look to his or her bar association for assistance with such problems. But in the last analysis the lawyer can only

\footnotetext{
${ }^{19} \mathrm{Cf}$. SimON, supra note 12, at 139 (referring to the lawyer as someone who should "service as an 'officer of the court' to both sympathetic identification with clients and detachment from them.").

${ }^{20}$ See Piero Calamandrei, Troppi avvocati! 73 (Quaderni della Voce, 1921).

${ }^{21}$ Within the Roman civil society, the profession of lawyer was originally exercised by noble people who offered their assistance, often as orators, to the plebeians due to their cultural status and social position, and without receiving any compensation.

${ }^{22}$ Tacito, AnNales, 5, Book XI.

${ }^{23}$ See supra note 15 , principle (e), 10.

${ }^{24}$ See supra note $16, \$ 2.7,10$.

${ }^{25}$ See supra note 17 , principle $5,2$.
} 
successfully represent his or her client if the lawyer can be relied on by the courts and by third parties as a trusted intermediary and as a participant in the fair administration of justice. ${ }^{26}$

The above paragraph contains in a few lines the dilemma of the legal profession and the contradictions revolving around its social function. The further interest that must be pursued by the lawyer in exercising her profession is a collective, general and public interest whose boundaries are extremely difficult to identify.

\section{Immanuel Kant - The Premier Moral Theory ${ }^{27}$}

After identifying the positivized deontological principles, I will try, as already mentioned, to transpose the deontological theory within Kant's moral philosophy and to analyze it in the light of the fundamental principles he proposed. Immanuel Kant could be considered one of the greatest and most influential thinkers in history, and certainly his doctrine remains "the premier moral theory." 28 The Metaphysics of Morals, published in 1797, probably contains Kant's most mature vision of ethics, morals and law. The goal set by Kant is to identify the essence of a universal morality valid for all human beings, and which cannot be influenced by the experience of a single one ${ }^{29}$ nor characterized by external perception.

Kant argues that in order to be able to identify a universal concept of morality it is necessary to conceive an "a priori knowledge," 30 something absolutely independent of all experience. This knowledge is supported by the observation of nature and the behavioral responses to the events that occur-despite the fact that these have never been experienced before-completely ignoring the experience and external perceptions.

Kant is obviously aware of the necessary connection between the human mind and the concept of moral law, so he gives his own interpretation. He recognizes that, although sensations and inclinations may influence our desires, a human being does not necessarily have to respond to these through the automatic satisfaction of sensible impulses (arbitrium brutum ${ }^{31}$ ). On the contrary, with the free will determined by reason, a person has the freedom to choose regardless of the external impulses.

Having laid the first foundations of his thought, Kant provides us with a very useful point of reflection in relation to the subject of my investigation. In fact, as a consequence of the assumptions identified above, he argues that:

In contrast to laws of nature, these laws of freedom are called moral laws. As directed merely to external actions and to their conformity to the law they are called juridical laws; but if they

\footnotetext{
${ }^{26}$ See supra note 15 , principle (i), 10 . This principle highlights how some of the behaviours required by the figure of the lawyer may not immediately pursue the client's interest, or may not lead to its univocal pursuit. It may therefore seem that the coder has a greater interest in ensuring the correct reliance of judges and third parties in the figure of the lawyer. In this way, the client's mediated interest would be better protected, and there would be a correct administration of the justice, whose effects will be also probably reproduced in the sphere of personal interests.

${ }^{27}$ See supra note 6 , at vii. In the Introduction, Sullivan tries to provide the reader with useful tools to reconstruct Kant's thought. After framing the work within Kant's literary production and having made an excursus on the terminology used by the philosopher, he provides a brief but precise reconstruction of how some emerging issues will be addressed and resolved. His introduction is certainly very useful for the purpose of a correct approach to the text.

${ }^{28} I d$. at vii. Sullivan defines Kant's theory as the premier moral theory saying that: "so influential have been his publications, however, that, like Plato before him, no one after him could do philosophy without taking him into account".

${ }^{29} \mathrm{Cf}$. Christine M. Korsgaard, Introduction to ImMAnuel Kant, Groundwork of the Metaphysics of Morals viii-xxx (Mary Gregor \& Jens Timmerman eds., Jens Timmerman trans., Cambridge University Press 2012).

${ }^{30}$ The concept of the 'a priori knowledge' is analytically introduced by Kant in his Critique of Pure Reason. See IMMANUEL Kant, Critique of Pure Reason (Paul Guyer \& Allen Wood trans., Cambridge University Press 1999).

${ }^{31}$ See KANT, supra note 6, at 13 [6:213]. ("Human choice, however, is a choice that can indeed be affected but not determined by impulses, and is therefore of itself (apart from an acquired proficiency of reason) not pure but can still be determined to actions by pure will.").
} 
also require that they (the laws) themselves be the determining grounds of actions, they are ethical laws, and then one says that conformity with juridical laws is the legality of an action and conformity with ethical laws is its morality. ${ }^{32}$

Therefore, Kant wants to underline the foundations that create the basis for the choice of a certain behavior which, to be considered ethical, must be self-motivated and self-sufficient-as justified by the laws of reason-in order to determine the exercise of the free will. ${ }^{33}$

So, according to Kant's vision, morality must find its foundation within the intrinsic rationality of every human being and in a free will understood in a purely transcendent sense. Moral laws find their source within our will— the pure will—as it is not influenced by any experiential and external elements. $^{34}$

In this perspective, moral laws are considered by Kant to be imperatives that prescribe positive or negative obligations, from which we cannot escape in any way. They are therefore categorical, and they identify the groundwork to be able to build our maxims of actions, which therefore become duties.

The representation of an action that is not considered necessary because of a particular aim or purpose, but directly as such, is capable of creating in itself a categorical imperative: A rule by which a contingent action is made necessary. And it is precisely the internal approach with duty that constitutes, according to Kant, the differentiating element in identifying what morality is "[...] considering the action in terms of moral laws, no special law would be required for it." ${ }^{35}$ Therefore, according to the Kantian conception, we are not subject to no other laws than those we give to ourselves.

From this conception derives the further difference between external and internal laws.

The external law is the one that becomes mandatory by virtue of the legislator who imposesor, better, encourages - compliance. But instead, the internal law concerns the motivational approach to action, differentiating natural law with positive law. In fact, if a rule imposed by the lawgiver was considered mandatory on the basis of a priori reasoning-even if the law itself was not contemplated in external law-this rule would fall under natural law. If this rule was instead considered mandatory because it is present within the regulatory system, then it should be considered a rule of positive law.

A rule that the agent herself makes her principle on subjective ground is called her maxim ${ }^{36}$ a principle by which the will to carry out or not an action is determined. In fact, action is not the fundamental point for determining what is moral and what is not, but it is the principle (incentives) on which the maxim used by the subject to determine his choices is based.

The lawgiver can be distinguished according to the incentives, which are a possible reason for action. If the lawgiver makes an action become a duty and a duty becomes an incentive to action, then he or she can be considered ethical; if instead the lawgiver admits an incentive other than the simple idea of duty, he or she can be considered juridical. ${ }^{37}$

\footnotetext{
${ }^{32}$ See KANT, supra note 6, at 14 [6:214].

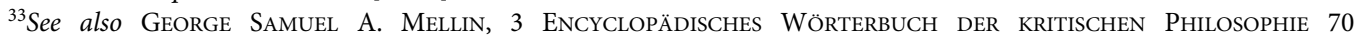
[Encyclopedic Dictionary of Critical Philosophy] (Friedrich Frommann ed.) (1803).

${ }^{34}$ See KANT, supra note 6.

${ }^{35} \mathrm{Id}$. at $16[6: 223]$.

${ }^{36}$ See KANT, supra note 6, at 17 [6:225] (referring to the concept of maxim: "A principle that makes certain action duties is a practical law. A rule that the agent himself makes his principle on subjective grounds is called maxim; hence different agents can have very different maxims with regard to the same law.").

${ }^{37}$ Regarding this concept, Kant states that: "A good will is not good because of what it effects of accomplishes, ... but only because of its volition that It is good in itself." Therefore, duty is moral only if it is duty in itself, without any external incentive and having as its object the will that underlies it, regardless of the action that is carried out. Cf. IMMANUEL KANT, Groundwork of The Metaphysics of Morals, at 10 (Mary Gregor \& Jens Timmerman eds., Cambridge University Press 2012).
} 
Acting in accordance with a rule without considering the incentives is called the "legality of the action;" while acting taking into accounts that the duty to act may be the incentive to action is called the "morality of the action." 38

The lawgiver will only be able to impose external duties because she cannot claim that the idea of duty itself can be the criterion of choice for the agent, and for this reason she will need external incentives that are suitable for the law. ${ }^{39}$

The ethical lawgiver is able to ensure that internal duties become a maxim for action, and that ethical behavior remains so even in the absence of external rules due to the correspondence between the maxim for action and the duty itself.

In this context, the difference between the duties of virtue ${ }^{40}$ and the duties of law is identified where precisely the fulfillment of a juridical duty corresponds to a law's one considered with the external incentives and its coercive force. Besides, the duties of virtue derive from the fulfillment of a duty as such, to which no coercive force could be applied other than an internal incentive represented by one's own free will.

Therefore, according to Kant, both ethics and law require the identification of principles on the basis of which to act externally, and whose actions are consistent with each other, but also different according to the source of the incentive. ${ }^{41}$

The Kantian analysis continues with the justification of the intervention of the juridical lawgiver aimed at encouraging and coercing the action of the human being. ${ }^{42}$ In fact, while acting is a metaphysical ${ }^{43}$ activity simply performed through the use of reason, the exercise of free will requires the human being to perform external actions. ${ }^{44}$ This combination necessarily leads human beings to act and enter into a relationship with each other.

Kant recognizes that not all human beings-when they decide to carry out an action-act in accordance with morality, observing a maxim based on the respect of the other's free will and on a hypothetical universal law. In fact, the human being could act according to other assumptions and further incentives, colliding with the freedom of choice of other human beings.

At the same time Kant argues that human beings who would like to act righteously and morally are not equally free if the judgment of "what seems right and good" 45 depends on their opinion. To face this conflict, in fact, they must move away from the state of nature and submit to a "public lawful external coercion, and so enter a condition in which what is to be recognized as belonging to it is determined by law and is allotted to it by adequate power." 46

The direct consequence of this possibility is that, if two freedoms collide with each other, one of the two deserves to be opposed. In the passage from a state of nature to a state of law (Rechtsstaat), human beings accept the idea of a superior force nourished by the consent of

\footnotetext{
${ }^{38}$ See supra note 6 , at 20 [6:219].

${ }^{39}$ Id. at 21 .

${ }^{40} I d$. at 21 [6:220].

${ }^{41} I d$. (explaining Kant's thought regarding the difference between the doctrine of virtues and the doctrine of law: "The doctrine of right and the doctrine of virtue are therefore distinguished not so much by their different duties as by the difference in their lawgiving, which connects one incentive of the other with the law.").

${ }^{42} I d$. at $25, \S \mathrm{D}$.

${ }^{43} I d$. at $24, \S \mathrm{C}$.

${ }^{44} I d$. at $\$ 2-6$. Kant stresses the need for human beings to perform actions in the sensible world according to the concept of free will, which must consequently accept the possibility of acting in the sensible world in order to be conceived. This point is clarified by Kant to justify the concept of possession.

${ }^{45} I d$. at 90 [6:312].

${ }^{46} I d$.
} 
plurality, ${ }^{47}$ which can guarantee each of them respect for their free will according to a universal law that has morality as its premise. $^{48}$

The legal legislator may therefore have the role of creating incentives for an action in order to prevent the free will of human beings from entering into conflict with each other.

\section{The Transition from Moral Duty to Juridical Duty}

The brief and perhaps incomplete reconstruction of Kantian thought on the moral question ${ }^{49}$ certainly offers some hints to connect his philosophical reflection with the problems underlying the conflict within the deontological codes.

In ictu oculi, for example, the adoption of positive law belonging to professional ethics could be identified as the activity performed by the Kantian juridical lawgiver in order to offer the agents (lawyers) external incentives (sanctions) to comply with duties probably born as moral, but which, due to the external non-obligatory nature of moral duties, become juridical thanks to a codification.

Having said that, the positivization of ethical duties should derive, as Kant says, from the simple evaluation of the same on the basis of an a priori reasoning that considers them compliant with the principle according to which the maxims of behavior, identified within them, respect other human beings free will and can be subsumed under Universal law. ${ }^{50}$

Moving slightly away from the Kantian thought, I could say that the individuation of the moral principles - to be transposed within the deontological codes - can derive from the recognition of the same as universally valid. Therefore, moral duties-subsequently to be transformed into juridical duties - would be considered those determined maxims of behavior that up to the moment of their positivization are applied autonomously by most lawyers ${ }^{51}$ in order to regulate the exercise of their profession, avoiding the presence of incentives other than the duty in itself. ${ }^{52}$

\footnotetext{
${ }^{47} I d$. at $\$ 7-8$. This concept is expressed by Kant when he justifies the possibility of a juridical possession of objects and the need, in order to guarantee it from the conflicting claims of others, that all human beings enter a state of law under the legislator.

${ }^{48} C f$. John S. Mill, ON Liberty 9 (Hackett Publishing Company 1978) (1859). In Mill's words, Kant's almost utilitarian vision appears "the only purpose for which power can be rightfully exercised over any member of a civilized community, against his will, is to prevent harm to others."

${ }^{49}$ For a more complete reconstruction of the Kantian idea of moral, without claiming to be exhaustive, see Simon Bacon, Legge e Abbligatorietà: La Struttura dell'idea di Autolegislazione Morale, 26 Studi KanTiani 55, 55-70 (2013); Kyla EbelsDuggan, Book Note, 122 Mind 488, 1098 (2013) (reviewing Thomas E. Hill, JR., VirTue, Rules, and JusticE: Kantian Aspirations (Oxford University Press 2013), https://doi.org/10.1093/mind/fzu005; R. McCarty, The Limits of Kantian Duty, and Beyond, 1 AM. PHIL. Q. 43, 43-52 (1989), http://www.jstor.org/stable/20014266; Jens Timmermann, Kant on Conscience, 'Indirect' Duty, and Moral Error, 3 InT'L PHIL. Q. 46, 293-308 (2006); W.G. Maclagan, The Nature of a Moral Duty, 107 PHIL. 28 (1953); W.J. Rees, The General Nature of a Moral Duty, 104 PHIL. 28, 41-57 (1953).

${ }^{50}$ See KANT, supra note 6, at 27 [6:230] (“Any action is right if it can coexist with everyone's freedom in accordance with a universal law, or if on its maxim the freedom of choice of each can coexist with everyone's freedom in accordance with universal law.").

${ }^{51}$ The distinction I have discussed is between Kant's "critical" morality and the view of a "conventional" morality. See, e.g., Patrick Devlin, The Enforcement of Morals (Oxford University Press 1965). The first theory tends to identify what is morally true, while, according to the second one, the moral meaning is what comes from trying to grasp what most people consider morally true. Devlin's conventional theory of morality has several weaknesses, as pointed out by John S. Mill who underlines the fact that opinions on moral issues change. In fact, by applying such a concept of morality, it would be difficult to understand whether the legal norms in force are applying dominant morality or the prejudices of the previous generation in society. See H. L. A. Hart, Law, Liberty and Morality (Oxford University Press 1963). See also Jeffrie G. Murphy, Legal Moralism and Retribution Revisited, CRIM. L. PHIL. 1, 5-20 (2007).

${ }^{52}$ B.H. Bix, JuRisprudence: TheOry And CONTEXT 157 (Sweet \& Maxwell eds., 2003). The relationship between law and morality in the deontological system is taken from the general correspondence also mentioned by Bix, who stated that "there is, and has always been, a large overlap between legal and moral standards."
} 
In this perspective, lawyers could be considered as custodians of an internal code of ethics based on moral duties subsequently transposed into positive law, which has transformed those moral duties into juridical.

The necessity of the legislator's intervention, even in the latter hypothesis, probably derives from the facts that-in accordance with the Kantian idea-despite human beings able to use reason to consider the maxims of moral behavior, their free will, influenced by external elementsinclinations, aversions, and more - can be at odds with what is right and good.

Therefore, even if the identification of the principles could derive from an a priori reasoning outside of external conditioning, the legal system has tried to recognize their relative value and has decided to ensure compliance regardless of the internal determinations of the agent exercising the legal profession.

\section{E. A Possible Conflict Resolution}

With these assumptions, the contrast between some rules enunciated in the supranational ethical codification and the identification of the Kantian idea of morality could be useful to grasp a final idea offered by the philosopher regarding the conflict between duties and/or obligations.

Kant argues precisely that the conflict between duties is a relationship where one of the two must necessarily eliminate the other. In fact, if duty is understood as an obligation expressed by the practical necessity of a certain action - and at the same time two opposite rules are considered for which opposite or incompatible actions are required-those rules could never identify two duties at the same time, but one of them will be a duty, while the other will be its opposite. ${ }^{53}$

From the conflict of rules (expression of moral duties) that I have considered on the basis of the Kantian thought, it should therefore derive that one of these, because of an internal conflict, does not originate from a moral duty, but it appears as a juridical duty only because it is imposed by the legislator.

According to this idea, choosing which interest may or may not correspond to a moral duty would probably be an objective too difficult to pursue, above all because of the different points of view about it.

Therefore, both doctrine of juridical positivism and Kantian thought ${ }^{54}$ highlight problems that are difficult to solve. In fact, considering the deontological rules such as the transposition of ethical or moral principles, the resolution of their conflict should derive from the exclusion of one of these, considering that, among those that contradict each other, only one could correspond to an ethical principle.

On the basis of the Kantian concept of morality, and on the affirmation according to which the intervention of an external lawgiver is in any case necessary, a further hypothesis for the conflict resolution could be identified-always within a Rechtsstaat-by a public and legal external coercion.

The intervention of the legislator could exclude directives that do not derive from moral duties, or try to find a way within the law to simultaneously respect all the conflicting duties.

Pursuing the principles of Kant, I will try to shift the attention from the ethical norms and related duties to the operative modalities of the forensic activity, assuming that the conflicting rules are all equally valid and based on fairly valid ethical principles.

\footnotetext{
${ }^{53}$ See KANT, supra note 6, at 19 [6:224] ("So a collision of duties and obligations is inconceivable (obligationes non colliduntur).").

${ }^{54}$ For an in-depth study of the various legal positivist conceptions, see, e.g., NORBERTO BobBIO, IL POSITIVISMO GIURIDICO (Giappichelli ed., 1996); Norberto Bobbio, Giusnaturalismo e Positivismo Giuridico (Comunità ed., 1972); Mauro Barberis, Etica Per i giUristi (Laterza ed., 2006); Mauro Barberis, Diritto e Morale: La Discussione Odierna, Revus 16, 55-93 (2011); John Austin, DelimitaZione del Campo della Giurisprudenza (Il Mulino ed., 1995).
} 
I will submit to the reader's critical scrutiny a solution that is still being studied and deepened, but which could offer an original point of view and also act as a stimulus for a broader reasoning and for a reinterpretation of the lawyer's social function.

In fact, as already mentioned, I believe a point of conjunction between the interests I have analyzed-whose protection is enshrined in the ethical codes - can be represented by the Alternative Dispute Resolution (ADR), and more specifically by the Assisted Negotiation Procedure.

The ADR procedures, in fact, by anticipating the protection of interests to a time prior to the judicial phase, could represent the most effective instrument for containing the conflict. One of the objectives of these procedures, in addition to the generally deflationary one, is to ensure the parties who access them a quick economic resolution of the dispute based on greater legal certainty; no longer left to the interpretation of an external and third party, but the result of the meeting of the parties' will assisted and addressed by their respective lawyers.

More specifically, the Assisted Negotiation Procedure, ${ }^{55}$ that was inspired by the French procédure participative de négociation assistée ${ }^{56}$ (known as "arbitration process" in Canada and "collaborative law" in the United States) $)^{57}$ is a process through which the parties involved in a dispute, thanks to the assistance of their respective lawyer, try to find a conciliatory agreement. Following the signing of the parties and the relative authentication by the lawyers, the agreement is valid as an enforceable and mortgage registration title. ${ }^{58}$

My idea is to evaluate whether the institution identified above can represent the modality through which the various interests prescribed by the deontological systems can be simultaneously satisfied, and at the same time verify whether this particular procedure can be linked to ethical and moral values.

The first factor emerging from a summary analysis of the institution is the identification of its ultimate goal: To have both parties-assisted by their respective lawyers-identify a possible agreement to definitively govern their relationship relating to a particular dispute.

Regarding the objective of the procedure, I could say that the agreement can flourish only in a terrain of sufficient justice. Therefore, despite an implicit, mutual, and partial recognition of the opposing claim - if the claim was fully recognized, the dispute would have no reason to arise - the party, at the time of reaching the agreement, would consider its interest sufficiently satisfied. Consequently, it could be argued that the client's interest, in the event of an agreement, in accordance with the law, is always sufficiently protected, both in terms of legal certainty, in civil law legal systems, and in purely economic and temporal terms.

Based on the assumptions identified above, it is necessary to understand whether reaching an agreement between the parties can also protect the interest for a proper administration of justice. It is also important to see it not only under the simple deflationary aspect, which is already in itself a general interest par excellence, but having regard to a general and supreme interest for which, in a state of law, the relational dynamics between its actors must be kept within balanced parameters dictated by law, aiming for justice and respecting everyone's freedom of choice.

Having defined what the administration of justice is, I can argue that the eventuality of reaching an agreement - based on the assumptions indicated above-can consistently represent a correct balance of various interests.

Furthermore, excluding judges or mediators from this procedure would reduce the risk of immoral actions that could easily conflict with the interests of the administration of justice, leaving intact the sole pursuit of this.

\footnotetext{
${ }^{55}$ The Assisted Negotiation procedure between lawyers came into force in Italy with the L.n. 2014/162 (It.) which converted with modifications the d.L.n. 2014/132 (It.).

${ }^{56}$ See Conseil National des Barreaux, Alternatives to Trial, https://www.avocat.fr/la-justice-et-moi/les-alternatives-auproces.

${ }^{57}$ Marco A. Quiroz Vitale, Schema Per Uno Studio Socio-Giuridico della Negoziazione Assistita in Italia, 4 SOCIETÀ E DiritTi. Rivista Elettronica 7, 11-31 (2017).

${ }^{58}$ Have a comparable value with that of a final judgement.
} 
Continuing to evaluate the ways in which the lawyer can escape the "Scylla" of the private interest and the "Charybdis" of the public interest, ${ }^{59}$ it is necessary to emphasize the position and condition of the lawyer. In fact, after arguing the effectiveness of the protection of various interests, it is necessary to verify whether the use of this procedure can also safeguard the concept of independence of the lawyer. By this I mean the absence of influences in the determination of the way to act based on different interests compared to the ones I previously took into consideration. It is precisely in this context that the ethical and moral discourse that permeates the legal profession must take into account the social function of the lawyer.

Far from adhering to an extreme vision, such as the one proposed in St. Thomas Aquinas's Summa Theologica, which stated “. . . Cum praestare patrocinium causae pauperum ad opus misericordiae pertineat" 60 (the defense of the poor man's suit belongs to the works of mercy), ${ }^{61} \mathrm{I}$ believe that the adoption of procedures such as the Assisted Negotiation necessarily requires the lawyers of the parties to make an effort to counterbalance the various interests at stake. Furthermore, it requires agreement with colleagues on the concept of what is right, so as to interface with their clients, induce and motivate them to take a step towards each other in order to move simultaneously for a goal greater than self-interest.

Literally, this is the moral value of a lawyer seeking to adopt the Assisted Negotiation procedure. In fact, even if Kant would not have considered entirely moral an action that includes external incentives, in this case provided by an external lawgiver, the lawyer and the parties alike, in seeking an agreement, must move within the boundaries of the law, all the while acknowledging and sufficiently respecting the freedom of choice of the other party. They are not obliged to adopt this procedure to find an agreement, but in case they find it, they have probably acted in the highest moral way possible.

The role of the lawyer would then become pervaded with ethical and moral values, and tending to what is right, as firmly stated by Dominici Soto in his work De Iustitia [et] iure libri decem: "Advocatus qui sciens et prudens iniustam causa defendit, tum mortaliter contra iustitiam peccat" 62 (the lawyer who defends an unjust cause commits a mortal sin).

The duty is therefore ethical, internal, and valid, and it originates from the free will to conform one's actions to a maxim of behavior that intends to allow the party to reorient its interests and claims in the light of justice. ${ }^{63}$

The exercise of the legal profession, within the defined perimeter, could be considered in the highest moral sense, precisely by virtue of the absence of external incentives for determining the principles on which to base one's behavior.

To summarize: For the conception of the social function of the lawyer-I have so far tried to propose-it will certainly be useful to use some concepts expressed by Massimo La Torre referring to Giovanni Cosi's theory: ${ }^{64}$

Conceived in this way, the lawyer undergoes a process of intellectual purification and moralization, 'which generates, so to speak, the judge in the client', making the latter less attentive

\footnotetext{
${ }^{59}$ See LA TORRE, supra note 18 , at 81.

${ }^{60}$ Thomas Aquinas, Summa Theologiae, II ${ }^{a}-I I a e$ q. 71 a. 1 co (1485).

${ }^{61} I d$. at Second Part I QQ I.-XXVI (Fathers of the English Dominican Province trans., Burns Oates and Washbourne, 1920).

${ }^{62}$ R.P.F. DOMINICI SOTO, DE IUSTITIA [et] IURE LIBRI DECEM (1594).

${ }^{63}$ See LA TORRE, supra note 18, at 150 (discussing the lawyer as a cooling entity, a term coined by Elio Fazzolari, referring to the lawyer as someone who cools the irons of the dispute).

${ }^{64} C f$. LUigi Lombardi VAlluri, Corsi Di Filosofia Del DiritTo 627 (Alessandro Ferrara trans., Cedam ed., 2012) (hoping that the lawyer, instead of intervening in a pathological phase of the dispute, will approach the figure of the judge -in the sense of impartiality and responsibility for any choice-anticipating the intervention of the judge in order to stimulate the resolution of disputes without entering the critical phase of the relationship).
} 
to his own selfish interests and orienting him instead to the common good, which is the ultimate goal of the legal system. ${ }^{65}$

This has a further consequence, which is to make a lawyer the bearer and champion of the morality of the legal system. ${ }^{66}$

\section{F. Conclusions}

The theory I have presented certainly cannot be considered without its critical points or weaknesses. First of all, we must consider the concrete imbalance that often occurs between the parties in a dispute - as in the obvious case in which one of the two is represented by the State or a public body-and between lawyers of different economic status. Second, there are borderline situations or controversial cases in which the identification of the element representing justice also refers to the determination of further moral principles, and therefore determines an evident difficulty for the lawyers themselves, whose opposite positions could be justified by the questionability of the matter.

Finally, in agreement with Kant, it is necessary to take into account perhaps the most frequent case that sees human beings not necessarily acting on the basis of moral principles, but always being subject to external stimuli, incentives, aversions and inclinations (homo brutus).

Despite this, the identification of a procedure that guarantees the simultaneous pursuit of apparently conflicting ethical duties would probably deserve a detailed study. Probably, such an identification also requires the identification of a system of incentives for the lawyers designed to reconcile all the possible interests at stake in a single direction, and to allow the legal lawgiver to approach the role of the ethical lawgiver. ${ }^{67}$

In doing so, the identification or rediscovery of the social role of a lawyer-aimed at "avoiding the degeneration of an interpersonal relationship into the pathological forms of a dispute," 68 rather than promoting it - could be considered a starting point towards the evolution of the lawyer into a preventive jurist ${ }^{69}$ bringing the ethical and moral principles that could represent the milestone on which to build her new social function into the sphere of the legal profession.

\footnotetext{
${ }^{65} \mathrm{Id}$. at 126.

${ }^{66} \mathrm{Id}$. at 127.

${ }^{67}$ There are several theories about the functionality of the positivization of the moral concepts. See, e.g., BRIAN H. BIX, A Dictionary Of Legal TheOry (Oxford University Press 2004) (arguing that they are based on "prudential" arguments, believing that the law should abstain from setting some moral goals as it is unsuitable for achieving them. The example of the Prohibition in the U.S. is often used to discuss this theory.). See also John M. Finnis, Liberalism and Natural Law Theory, 45 MERCERY L. REv. (1994) (showing that, as for the nature of things, no one can be forced to act morally through the threat of a legal sanction). This is because the nature of moral action is the free will, in accordance with the Kantian view, and the choices imposed by the fear of sanctions could, from the outside, induce individuals to conform to some choices required by an ethical code; however, from an inner point of view, these choices will have any fundamental determination or intention. But see Ronald Dworkin, Liberal Community, 77 CALIF. L. REV. 3 (1989) (arguing that, if the positivization of the moral principles help to abandon an immoral life, it might not be possible to achieve the goal of improving someone's life "even though he endorsed the change we brought about, if the mechanisms we used to secure the change lessened his ability to consider the critical merits of the change in a reflective way.").

An opposite and paternalistic view is offered by Joseph Raz. See Joseph Raz, Liberty and Trust, in NATURAL LAW, LIBERALISM AND Morality: Contemporary Essay (Robert P. George ed., Clarendon Press 1996). According to Raz, the government occupies an important place in the elaboration of the options available to its citizens, but, nevertheless, the justification of a coercive paternalism, according to which obliged people live better, as coercion is justified by the idea of a better society because it is made up of fewer people who behave in an immoral way, has to deal with a correlated and different value: People's autonomy and the freedom.

${ }^{68}$ See LA TORRE, supra note 18 , at 125.

${ }^{69}$ See Giovanni Cosi, La responsabilita del giUrista. Etica E Professione Legale 311 (Giappichelli, 1998).
} 